\title{
PALAEOCLIMATIC AND PALAEOCEANOGRAPHIC EVOLUTION OF THE MEDITERRANEAN SEA OVER THE LAST 18KA
}

\author{
Thomopoulos K., Geraga M., Fakiris E., Papatheodorou G. \\ and Ferentinos G. \\ University of Patras, Department of Geology, Laboratory of Marine Geology and Physical Oceanography, \\ 26500 Patras,Greece,mgeraga@upatras.gr
}

\begin{abstract}
The aim of the present study is the reconstruction of the palaeoclimatic and palaeoceanographic evaluation of the Mediterranean Sea over the last 18ka based on the distribution of the planktonic foraminifera species. Planktonic foraminifera species have been proven excellent indicators of the palaeoclimatic and palaeoceanographic variability.

The data set of the present study consists of the variability in the abundances of planktonic foraminifera species as has been reported and published in previous studies, after the examination of marine sediments from cores selected all over the Mediterranean Sea. The evolution in the abundance of each planktonic species is examined on a time interval spacing of 1000years suggesting implications for the palaeoclimatic and palaeoceanographic evolution of the Mediterranean Sea for the same time sampling interval (1000yrs). The most pronounced results of this study suggest that: (i) the increase in surface temperature during the warm intervals always follow a decreasing trend from eastern to western areas, (ii) the eutrophication of the Mediterranean Sea in most of the time exhibits a decreasing trend from northern to southern areas, and (iii) during the Holocene two cool spells (at around $8 \mathrm{ka}$ and $4 \mathrm{ka}$ ) seems that had affected the majority of the Mediterranean region.
\end{abstract}

Key words: plantkonic foraminifera, spline analysis, palaeoceanographic variability, late postglacial, Mediterranean Sea.

\section{Introduction}

Planktonic foraminifera have proven to be reliable indicators in palaeoceanographic and palaeoclimatic Quaternary studies. Variations in the abundance of selected species correlate with changes in sea surface temperature, in salinity, in food availability and in general changes in the state of the prevailing hydrographic systems in the water column (e.g. Pujol and Vergnaud-Grazzini, 1995). In addition, changes in planktonic foraminifera can be used in biochronology. Within this concept, during the last decades a large number of works publish records of the planktonic foraminifera abundances, obtained from sediment cores, selected from Mediterranean Sea, in order to present the local palaeoceanographic history (Triantaphyllou et al., 2009; Geraga et al., 2010). Thus, a lot of information has been collected regarding long and short duration of paleoceanographic and palaeoclimatic changes.

In this work an effort has been made to collect most of the above data and to present it under a common chronostratigraphic framework. Furthermore the evolution of the spatial distribution in Mediter- 


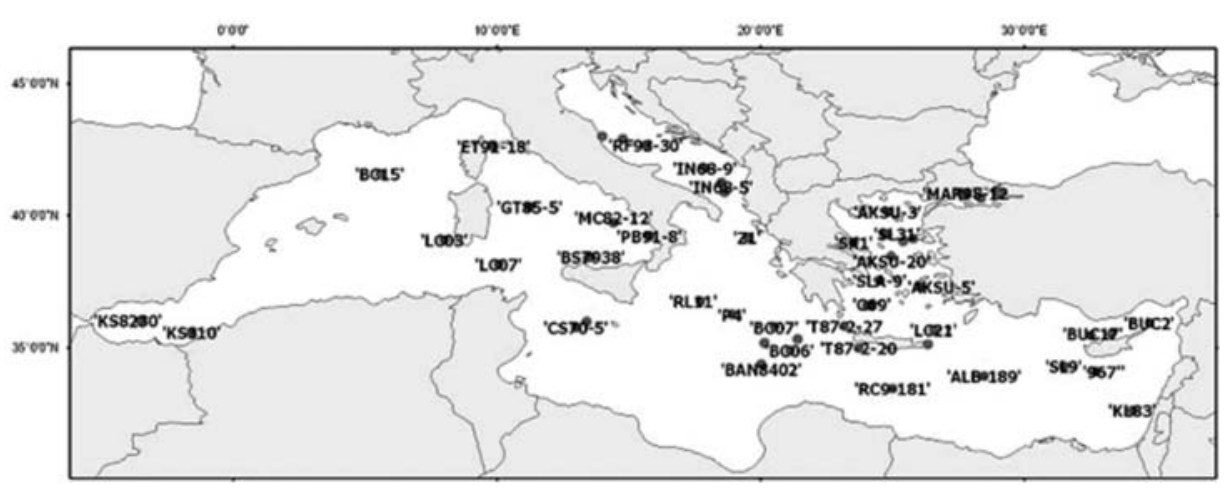

Fig. 1: Map showing the location of the core sediment, used for the construction of the data base of the present work. (SK1: Zachariasse et al., 1997; IN68-9, LC21: De Rijk et al., 1997; KS8230, RL11, ODP967: Emeis et al., 2000; SL11, SL21, SL31, SLA-9: Casford et al., 2002 and Casford et al., 2003; BS7937, BS7938: Sbaffi et al., 2004; AD91-17: Sangiorgi 2003; AGE-5, AEG-3, AGE-19, AGE-20: Aksu et al., 1995; SL9: Principato et al., 2006; T87-2-13G, T87-2-27G, T87-2-20G: Rohling et al., 1993; IN68-5, IN68-21, CS73-34, BS78-12: Jorrisen et al., 1993; RF93-30: Oldfield et al., 2003; ET91-18, GT85-5, PB91-2, PB91-8: Capotondi et al., 1999; ALB-189, RC9-181, KS-09: Cita et al., 1977; MAR97-02, MAR94-05, MAR97-11, MAR98-12, MAR98-07, MAR98-09: Aksu et al., 2002; BC02, BC06, BC07: Principato et al., 2003; MC82-12: Ariztegui et al., 2000; BAN8402, BAN8408: Olausson 1991; CS70-5: Vergnaud-Grazzini et al., 1988; KS310, BC15, LC03, LC07, P4: Hayes et al., 1999; BUC2, BUC12, BUC17: Bukley et al., 1982; C40: Geraga et al., 2000; C69: Geraga et al., 2005; Z1: Geraga et al., 2004; GeoTU KL83: Sperling et al., 2003; NS-14 Triantafyllou et al., 2007).

ranean Sea, of selected plantkonic foraminifera species, following a time interval of 1000years, over the last 18000years, is discussed.

\section{Methods}

This work is based on the micropaleontological data from 59 sediment cores, published between 1977 and 2006, covering the entire Mediterranean Sea (Fig. 1). A data base was established based on the $\delta^{18} \mathrm{O}$ values and the relative abundances of Globigerinoides ruber, Globigerina bulloides, Globorotalia inflata and Neogloboquadrina pachyderma, presented in these works.

A common chronostratigraphic framework was determined for all records based on the datings given in these papers in conjunction to the sedimentation rate and the presence of chronostratigraphic horizons (e.g. tephra layers, sapropel S1, isotopic stages, biozones). All the ages were calibrated using the program "calib 5.01" (Stuiver and Reimer, 1993; Reimer, 2000) taken into consideration local values for reservoir effect and $\Delta \mathrm{R}$ values.

For the purposes of this work, the data base was treated by Splines interpolating method (Fritsch and Carlson, 1980; Kahaner, et al., 1989), produced in MATLAB programming environment, thus all data could be presented with a time sampling interval of 1000years.

The final step included the construction of maps in ArcGIS environment, indicating the spatial distribution of each taxon in Mediterranean Sea, every 1000yrs.

\section{Results and discussion}

The distribution of the $\delta^{18} \mathrm{O}$ values shows that over the last 18000years eastern Mediterranean Sea 

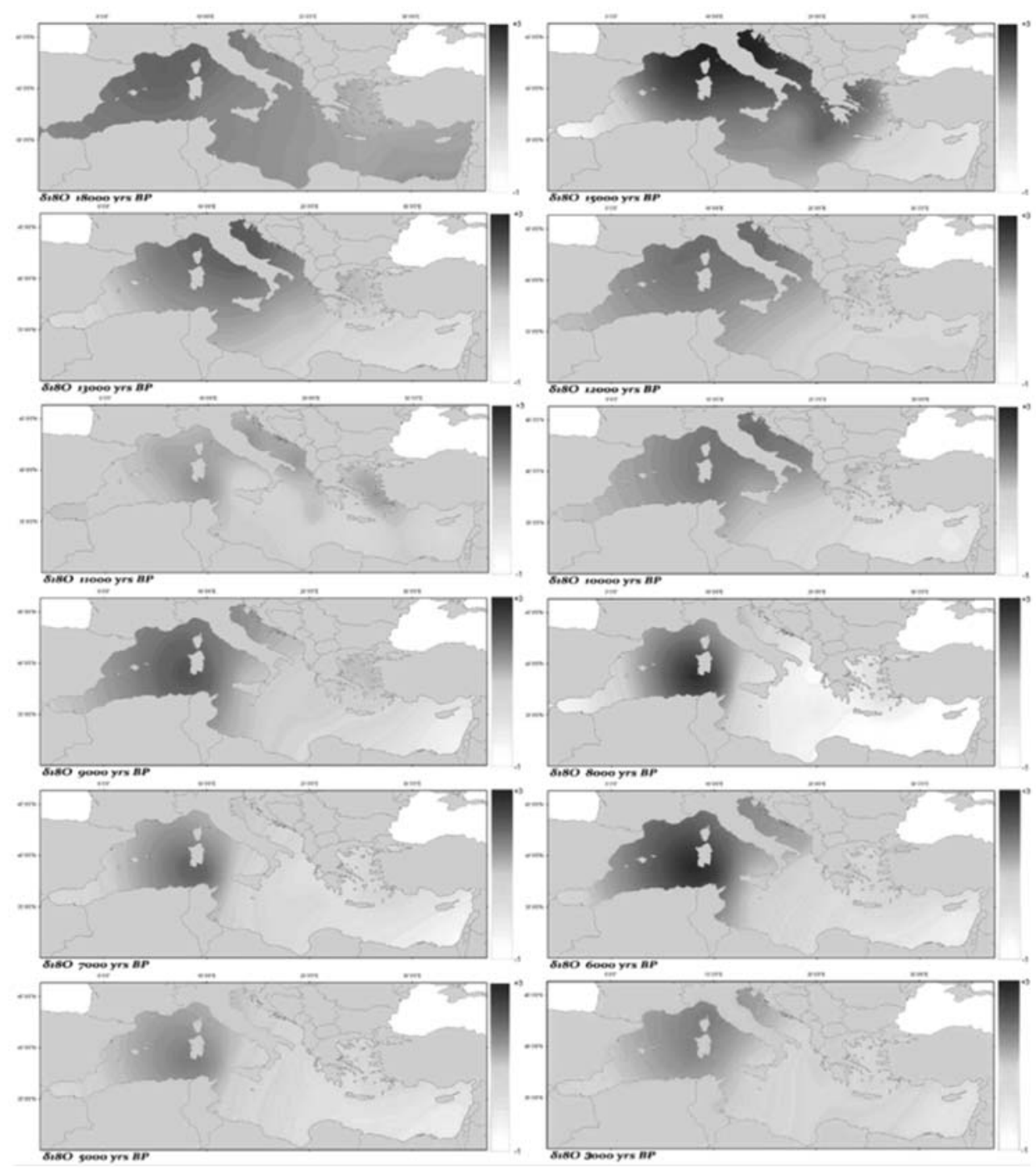

Fig. 2: Maps showing the variation in the distribution of the $\delta^{18} \mathrm{O}$ values in the Mediterranean Sea over the last 18000years (see Fig. 1 for the location of the data points).

presents always lower values in relation to the western Mediterranean Sea (Fig. 2). During the last glacial period all the Mediterranean Sea exhibits high positive $\delta^{18} \mathrm{O}$ values, although this signal is stronger in the western Mediterranean Sea. The improvement of climate during the late glacial period is more pronounced at the eastern Mediterranean Sea and the establishment of Younger Dryas event (12-11ka) occurs all over the Mediterranean Sea. During the Holocene the most depleted $\delta^{18} \mathrm{O}$ values occurs between 9 and $8 \mathrm{ka}$ at the eastern Mediterranean sea and coincides with the deposition of the sapropel S1a. Furthermore climatic deteriorations obtained as shifts to more heavy $\delta^{18} \mathrm{O}$ values occurs for the entire Mediterranean sea at around 8, 6 and $4 \mathrm{ka}$, although this signal is more pronounced in western Mediterranean Sea. These cold spells coincide in age with cold events recorded in high latitude areas (Bond et al., 1997). 

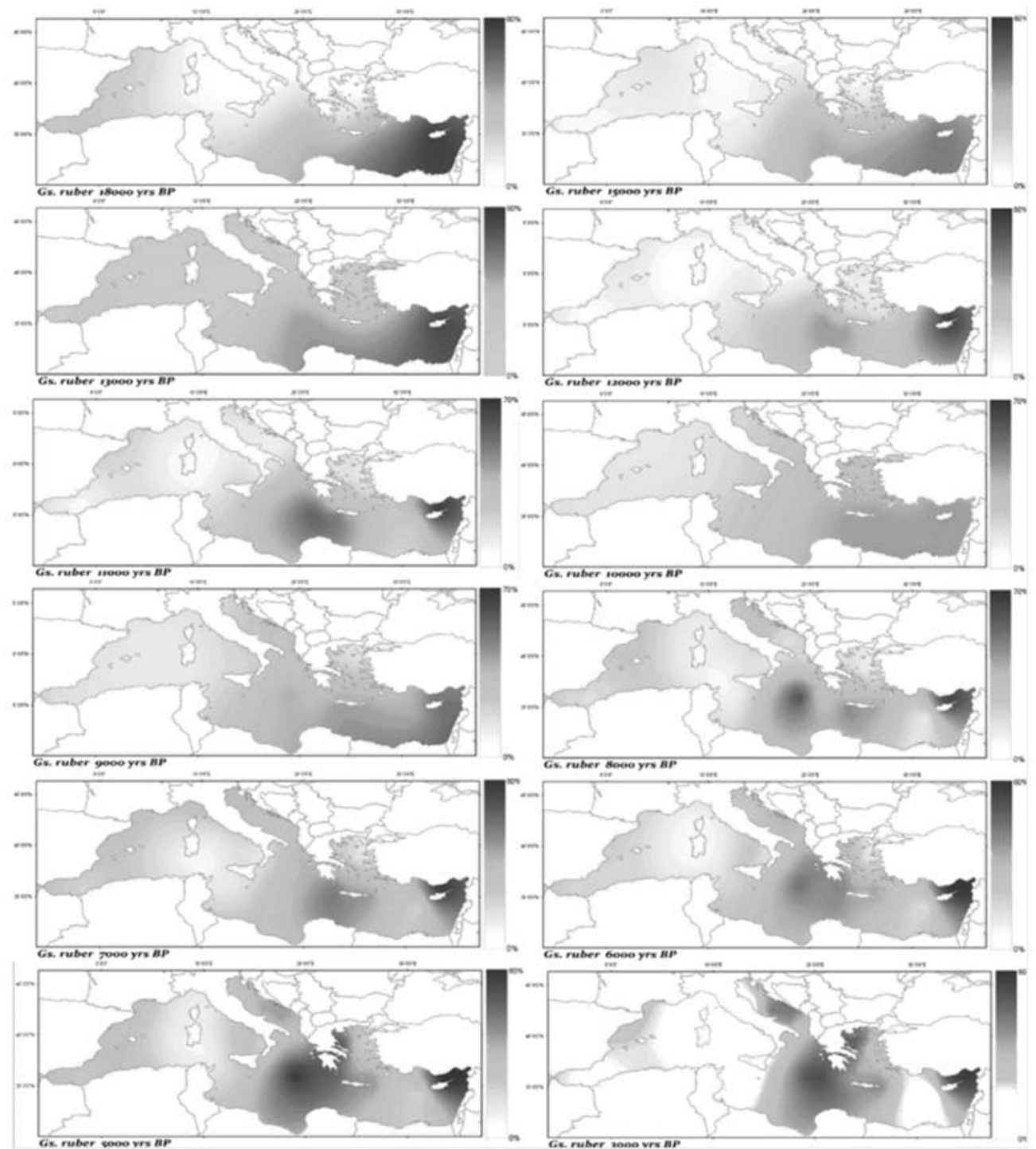

Fig. 3: Maps showing the variation in the distribution of the relative abundances of Gs. ruber in the Mediterranean Sea over the last 18000years (see Fig. 1 for the location of the data points).

Gs. ruber prefers warm and oligotrophic waters (Thunell, 1978; Pujol and Vergnaud Grazzini, 1995). The higher abundances of this species occur at the eastern Mediterranean (Fig. 3) for most of the discussed period (last 18kyrs) suggesting the prevalence of warm and stratified waters at the area and the development of more oligotrophic conditions in relation to the central and the western Mediterranean Seas. By the 7000 yrs BP the distribution of this species is similar to that obtained by Pujol and Vergnaud Grazzini (1995) which studied live planktonic foraminifera along a W-E axis parallel to the North African coast. Over the last 3000years, high abundances of Gs.ruber also occur at the eastern Adriatic, Ionian and Aegean Seas. 


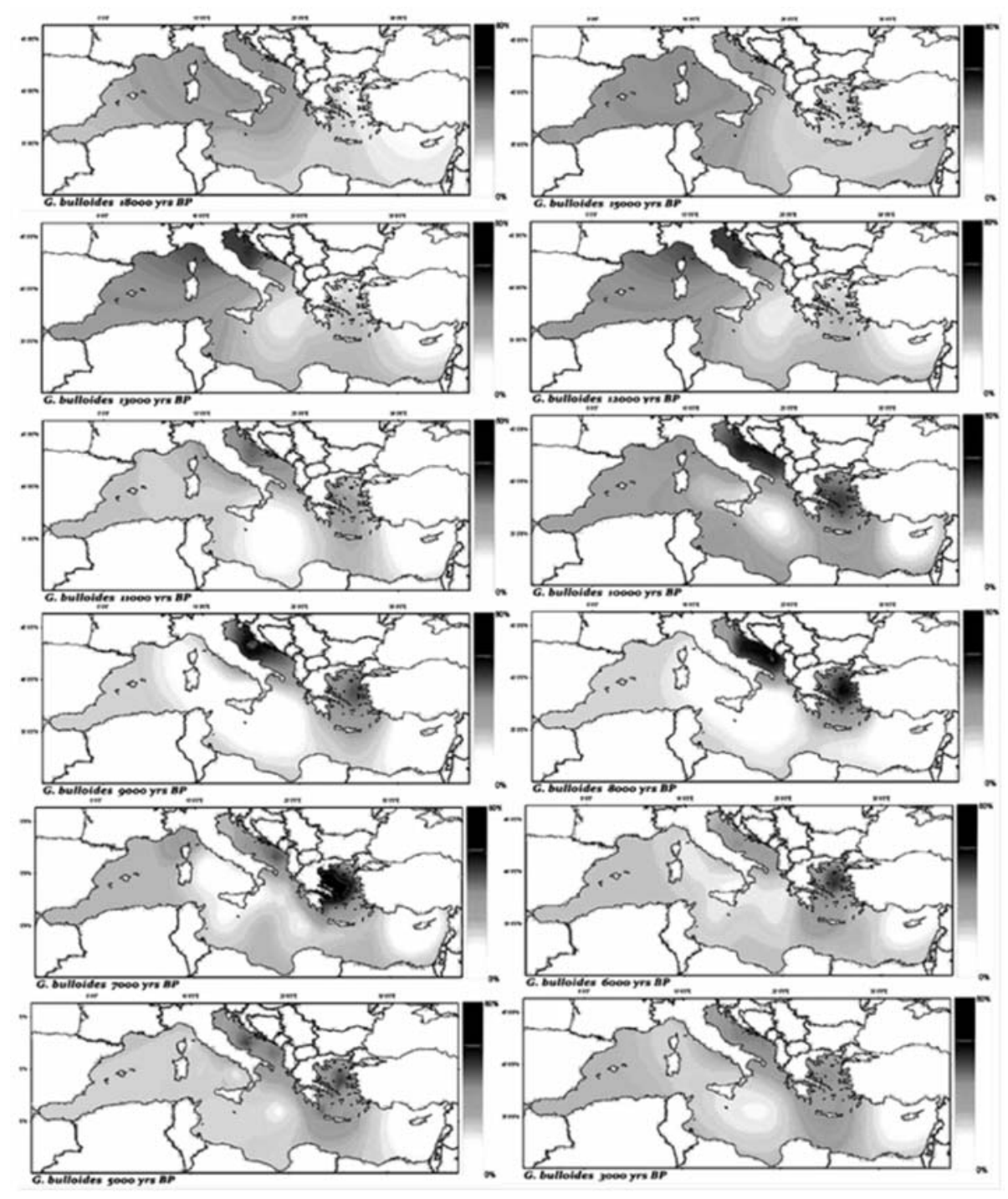

Fig. 4: Maps showing the variation in the distribution of the relative abundances of G. bulloides in the Mediterranean Sea over the last 18000years (see Fig. 1 for the location of the data points).

G. bulloides may be found from subpolar to tropical regions and has been associated with high fertility waters in upwelling areas, boundary currents and river discharges (Thunell, 1978; Pujol and Vergnaud Grazzini, 1995). During the glacial period this species appear in high abundance at the northern areas of the western and central Mediterranean Sea (Fig. 4). The development of the eutrophication at this area is complex and is related to frontal systems, boundary currents and river runoffs. Probably was the latter factor that led to the high frequencies of G. bulloides during the Late Glacial Period. Between 10 and 7ka the distribution $\mathrm{f} G$. bulloides exhibits higher abundance in the eastern Mediterranean Sea. Then it shows maximum frequencies at the Adriatic and Aegean Seas probably in association with increased precipitation and increased river runoffs. 


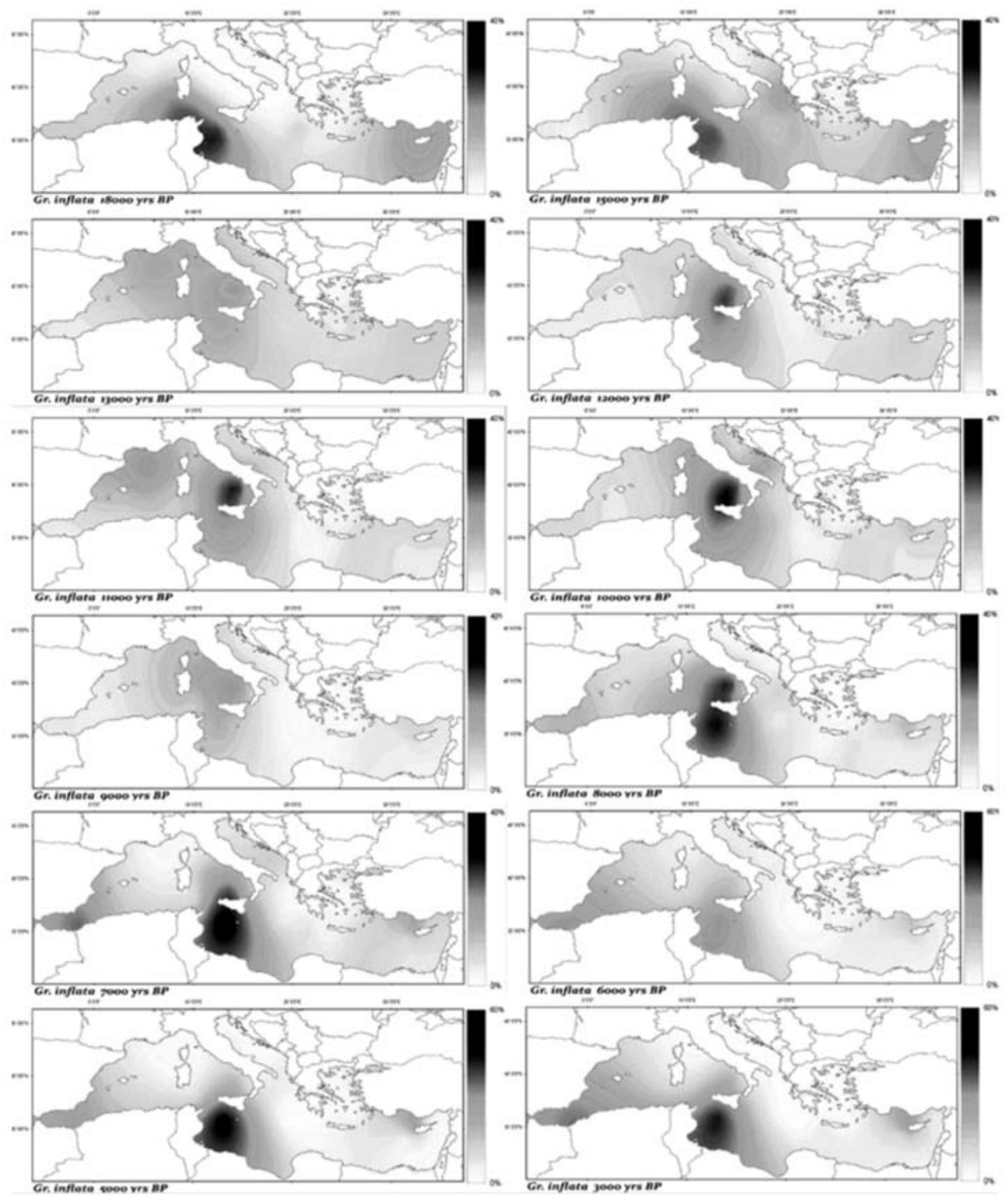

Fig. 5: Maps showing the variation in the distribution of the relative abundances of $G$. inflata in the Mediterranean Sea over the last 18000years (see Fig. 1 for the location of the data points).

G. inflata is associated with cool and winter deep mixing waters (Thunell, 1978; Pujol and Vergnaud Grazzini, 1995). Today, Pujol and Verganud Grazzini (1995) have found high abundances of this species in the Alboran Sea and along the North African coast (close to Sicily Straits). These areas coincide with both the path of the Modified Atlantic Waters and that of the Levantine Intermediate Waters. This distribution pattern of G. inflata occurs since the 7000yrs BP (Fig. 5). During the glacial period high frequencies of this species occurs along the North African coast and occasionally in the Tyrrhenian Sea suggesting probably an N-S displacement of the frontal system and of the relevant anticyclone developed in the area. 

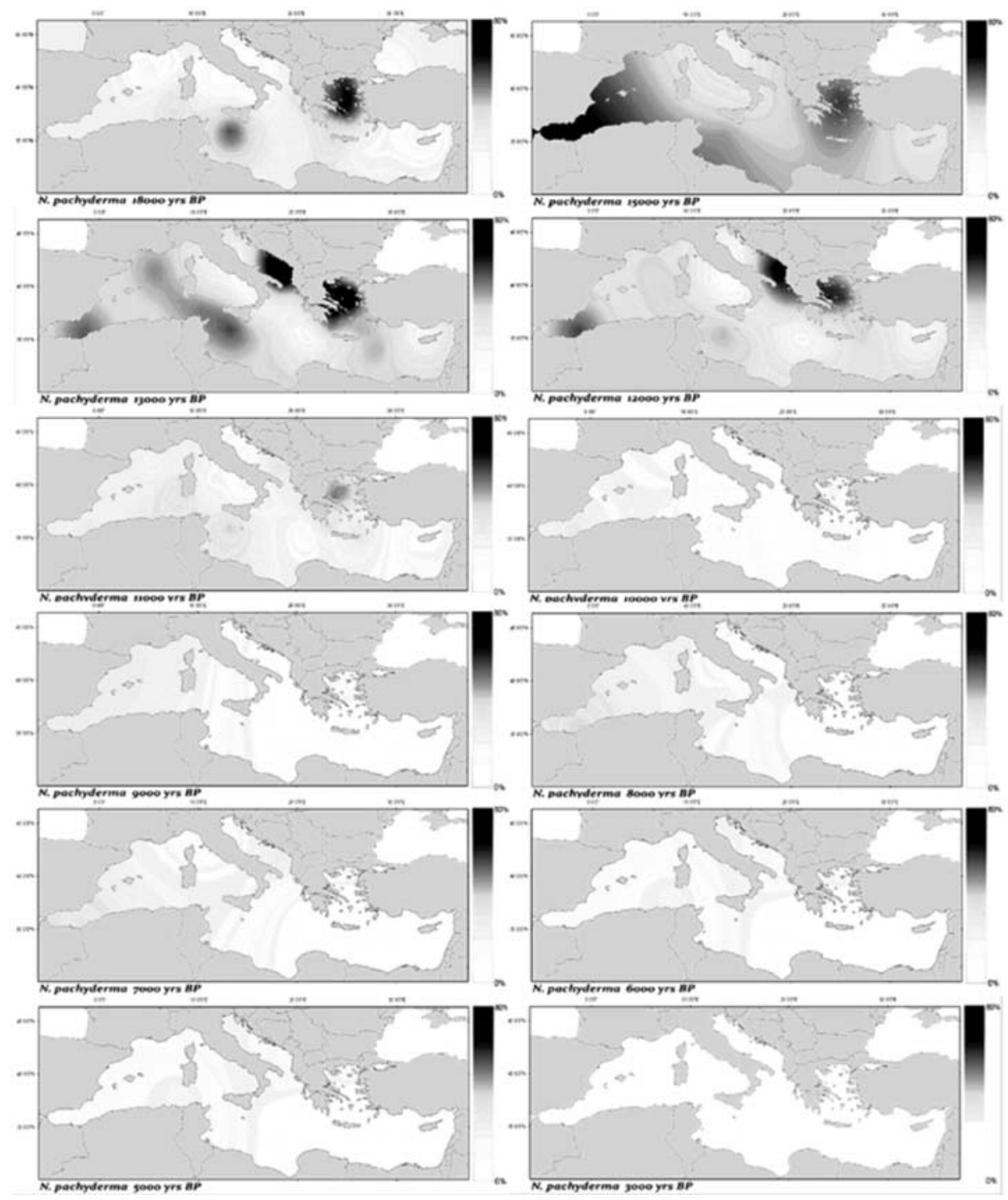

Fig. 6: Maps showing the variation in the distribution of the relative abundances of $N$. pachyderma in the Mediterranean Sea over the last 18000years (see Fig. 1 for the location of the data points).

N. pachyderma occurs from subpolar to tropical regions and is associated with temperatures lower than $12^{\circ} \mathrm{C}$ and the development of a Deep Chlorophyl Maximu (DCM) layer (Thunell, 1978; Pujol and Vergnaud Grazzini, 1995). In the Mediterranean Sea, high frequencies of this species occur only during the glacial period whilst during the Holocene its distribution is very limited (Fig. 6). Between 18 and 17kyrs BP, this species occurs in high abundance at the Aegean Sea and close to the Sicily straits. During the late glacial period increased frequencies of this species occur also at the Alboran, Balearic, Tyrrhenian and Adriatic Seas. Its high abundance at the western Mediterranean Sea may be associated with the enhanced flows of the Atlantic waters, whilst that at the Aegean Sea (during the Last Glacial Maximum) with the shoaling of the pycnocline (Rohling and Gieskes, 1989). 


\section{Conclusions}

The distribution of the abundance of selected planktonic foraminifera species together with the $\delta^{18} \mathrm{O}$ values showed that warmer and more oligotrophic waters prevailed for most of the discussed period in the eastern Mediterranean Sea in relation to the western Mediterranean Sea. The climatic improvement always starts at eastern Mediterranean and follows a western-wards trend. The most eutrophicated conditions in eastern Mediterranean Sea prevailed during the deposition of S1a. Furthermore Mediterranean Sea appears to respond to cold events recorded to high latitude areas during the glacial and Holocene periods, although this signal is always more pronounced in the western Mediterranean Sea.

\section{References}

Aksu, A.E., Yasar, D., Mudie, P.J., 1995. Late glacial-Holocene paleoclimatic and paleoceanographic evolution of the Aegean Sea: micropaleontological and stable isotopic evidences, Marine Micropaleontology 25, 1-28.

Aksu, A.E., Hiscott, R.N., Kaminski, M.A., Mudie, P.T., Gillespie, H., Abrajano, T., Yasar, D., 2002. Last glacial - Holocene paleoceanography of the Black Sea and Marmara Sea: stable isotopic, foraminiferal and coccolith evidence, Marine Geology 190, 119-149.

Ariztegui, D., Asioli, A., Lowe, J.J., Trincardi, F., Vigliotti, L., Tamburini, F., Chondrogianni, C., Accorsi, C.A., Bandini Mazzanti, M., Mercuri, A.M., Van der Kaars, S., McKenzie, J.A., Oldfield, F., 2000. Palaeoclimate and the formation of sapropel S1:inferences from Late Quaternary lacustrine and marine sequences in the central Mediterranean region, Palaeogeography, Palaeoclimatology, Palaeoecology, 158, 215-240.

Bond, G., Showers, W., Cheseby, M., Lotti, R., Almasi, P., de Menocal, P., Priore, P., Cullen, H., Hadjas, I., Bonani, G., 1997. A pervasive millennial scale cycle in North Atlantic Holocene and glacial climates, Science 278, 1257-1266.

Buckley, H.A., Johnson, L.R., Shackleton, N.J., Blow, R.A., 1982. Late glacial to recent sediment cores from the eastern Mediterranean, Deep-Sea Research 29, 739-766.

Casford, J.S.L., Rohling, E.J., Abu-Zied, R., Cooke, S., Fontanier, C., Leng, M., Lykousis, V., 2002. Circulation changes and nutrient concentrations in the late Quaternary Aegean Sea: a nonsteady state concept for sapropel formation, Paleoceanography, 17, 1024-1034.

Casford, J.S.L., Rohling, E.J., Abu-Zied, R.H., Fontanier, C., Jorissen, F.G., Leng, M.G., Schmiedl, G., Thomson, J. 2003. A dynamic concept for eastern Mediterranean circulation and oxygenation during sapropel formation, Palaeogeography, Palaeoclimatology, Palaeoecology, 190, 103-119.

Capotondi, L., Borsetti, A.M., Morigi, C., 1999. Foraminiferal ecozones, a high resolution proxy for the late Quaternary biochronology in the central Mediterranean Sea, Marine Geology, 153, 253-274.

Cita, M.B., Vergnaud-Grazzini, C., Robert, C., Chamley, H., Ciaranfi, N., D’Onofrio, S., 1977. Palaeoclimatic record of a long deep sea core from the eastern Mediterranean, Quaternary Research 8, 205-235.

De Rijk, S., Hayes, A., Rohling, E.J., 1999. Eastern Mediterranean sapropel S1 interruption:an expression of the onset of climatic deterioration around 7 ka BP, Marine Geology, 153, 337-343.

Emeis, K.C., Struck, U., Schulz, H.M., Rosenberg, R., Bernasconi, S., Erlenkeuser, H., Sakamoto, T., Martinez-Ruiz, F., 2000. Temperature and salinity variations of Mediterranean Sea surface waters over the last 16,000 years from records of planktonic stable oxygen isotopes and alkenone unsaturation ratios, Palaeogeography, Palaeoclimatology, Palaeoecology, 158, 259-280.

Fritsch, F.N., and Carlson, R.E., 1980. Monotone Piecewise Cubic Interpolation, SIAM J. Numerical analysis. 17, 238-246

Geraga, M., Tsaila-Monopoli, St., Ioakim, Ch., Papatheodorou, G., Ferentinos, G. 2000. An evaluation of 
paleoenvironmental changes during the last 18000yrs BP in the Myrtoon Basin, S.W. Aegean Sea, Palaeogeography, Palaeoclimatology, Palaeoecology, 156, 1-17.

Geraga, M., Tsaila-Monopoli, St., Ioakim, Ch., Papatheodorou, G., Ferentinos, G. 2005. Short-term climate changes in the southern Aegean Sea over the last 48000 years, Palaeogeography, Palaeoclimatology, Palaeoecology, 220, 311-332.

Geraga, M., Mylona, G., Tsaila-Monopolis, St., Papatheodorou, G., Ferentinos, G., 2004. Micropaleonological study of the core sediment Z1 from the Ionian Sea, Proceedings of the $10^{\text {th }}$ International Congress, Thessaloniki, April 2004, Bulletin of the Geological Society of Greece, 245-253 (in Greek).

Geraga, M, Ioakim, Chr, Lykousis, V., Tsaila-Monopolis, St, Mylona, G. 2010. The high-resolution palaeoclimatic and palaeoceanographic history of the last 24,000 years in the central Aegean Sea, Greece, Palaeogeography, Palaeoclimatology, Palaeoecology, 287, 101-115.

Hayes, A., Rohling, E.J., De Rijk, S., Kroon, D., Zachariasse, W.J., 1999. Mediterranean planktonic foraminiferal faunas during the last glacial cycle, Marine Geology, 153, 239-252.

Jorissen, F.J., Asioli, A., Borsetti, A.M., Capotondi, L., De Visser, J.P., Hilgen, F.J., Rohling, E.J., Van der Borg, K., Vergnaud-Grazzini, C., Zachariasse, W.J. 1993. Late Quaternary central Mediterranean biochronology, Marine Micropaleontology, 21, 169-189.

Kahaner D, Moler, C., Nash, S., 1989. Numerical Methods and Software, Upper Saddle River, NJ, USA, Prentice-Hall Inc, 495pp.

Olausson, E., 1991.Carbon and oxygen isotope composition of foraminifera in two cores from the Bannock Basin area, eastern Mediterranean, Marine Geology, 100, 45-51.

Oldfield, F., Asioli, A., Accorsi, C.A., Mercuri, A.M., Juggins, S., Langone, L., Rolph, T., Trincardi, F., Wolff, G., Gibbs, F., Vigliotti, L., Frignani, M., Van der Pos, K., Branch, N. 2003. A high resolution late Holocene palaeo environmental record from the central Adriatic Sea, Quaternary Science Reviews, 22, 319-342.

Principato, M.S., Giunta, S., Corselli, C., Negri, A., 2003. Late Pleistocene/Holocene planktonic assemblages in three box-cores from the Mediterranean Ridge area (W-SW of Crete): paleoecological and paleoceanographic reconstruction of sapropel S1 interval, Palaeogeography, Palaeoclimatology, Palaeoecology, 190, 61-77.

Principato, M.S., Crudeli, D., Ziveri, P., Slomp, C.P., Corselli, C., Erba, E., De Lange, G.J. 2006. Phytoand zooplankton paleofluxes during the deposition of sapropel S1 (eastern Mediterranean): Biogenic carbonate preservation and paleoecological implications, Palaeogeography, Palaeoclimatology, Palaeoecology, 235, 8 -27.

Pujol,C., and Vergnaud Grazzini, C., 1995. Distribution patterns of live planktic foraminifers as related to regional hydrography and productive systems of the Mediterranean Sea, Marine Micropaleontology 25, 187-217.

Reimer, P., 2000. Marine reservoir correction database. www Page, http://calib.qub.ac.uk/marine/

Rohling, E.J., Gieskes, W.W.C., 1989. Late Quaternary changes in Mediterranean Intermediate Water density and formation. Paleoceanography, 4, 531-545.

Rohling, E.J., Jorissen, F.J., Vergnaud-Grazzini, C., Zachariasse, W.J., 1993. Northern Levantine and Adriatic Quaternary planktic foraminifera; reconstruction of paleoenvironmental gradients, Marine Micropaleontology, 21, 191-218.

Sangiorgi, F., Capotondi, L., Combourieu Nebout, N., Viglioti, L., Brinkhuis, H., Giunta, S., Lotter, A., Morigi, C., Negri, A., Reichart, G. 2003. Holocene seasonal sea-surface temperature variations in the southern Adriatic Sea inferred from a multiproxy approach, Journal of Quaternary Science, 18, 723-732.

Sbaffi, L., Wezel, F.C., Curzi, G., Zoppi, U. 2004. Millenial to centennial scale paleoclimatic variations 
during Termination I and the Holocene in the central Mediterranean sea, Global and Planetary Change, 40, 201-217.

Sperling, M., Schmiedl, G., Hemleben, Ch., Emeis, K.C., Erlenkeuser, H., Grootes, P.M. 2003. Black Sea impact on the formation of eastern Mediterranean sapropel S1? Evidence from the Marmara Sea, Palaeogeography, Palaeoclimatology, Palaeoecology, 190, 9-21.

Stuiver, M. and Reimer, P.J., 1993. Extended ${ }^{14} \mathrm{C}$ database and revised CALIB radiocarbon program. Radiocarbon, 35, 215-230.

Thunell, R.C. 1978. Distribution of recent planktonic foraminifera in surface sediments of the Mediterranean Sea, Marine Micropaleontology, 3, 147-173.

Triantaphyllou, M.V., Antonarakou, A., Kouli, K., Dimiza, M., Kontakiotis, G., Ziveri, P., Mortyn, G., Lykousis, V., Dermitzakis, M.D. 2007. Plankton ecostratigrafy and pollen assemblage zones over the last 14000 years in SE Aegean Sea. (core NS-14).Proceedings of the $11^{\text {th }}$ International Congress, Athens, May 2007, Bulletin of the Geological Society of Greece, 209-224.

Triantaphyllou, M. V., Antonarakou, A., Kouli, K., Dimiza, M., Kontakiotis, G., Papanikolaou, M., Ziveri, P., Mortyn, P.G., Lianou, V., Lykousis, V., Dermitzakis, M. D. 2009. Late Glacial-Holocene ecostratigraphy of the south-eastern Aegean Sea, based on plankton and pollen assemblages. Geo-Marine Letters, 29, 249-267.

Vergnaud-Grazzini, C., Borsetti, A.M., Cati, F., Colantoni, P., D’onofrio, S., Saliege, J.F., Sartory, R., Tampiery, R. 1988. Paleoceanographic record of the last deglaciation in the strait of Sicily. Marine Micropaleontology, 13, 1-21.

Zachariasse, W.J., Jorissen, F.J., Perissoratis, C., Rohling, E.J., Tsapralis, V. 1997. Late quaternary foraminiferal changes and the nature of sapropel S1 in skopelos basin. Proceedings $5^{\text {th }}$ Hellenic symposium on Oceanography and Fisheries, Kavalla, Greece, Vol. 1, 391-394. 